\title{
Remittances and the Growth of the Nigerian Economy
}

\author{
Margaret Abiola Loto ${ }^{1}$ and Ajibola Akinyemi Alao ${ }^{2}$
}

\begin{abstract}
The study investigated the contributions of foreign remittances on economic growth in Nigeria from 1980 to 2016, using the Vector error correction modelling (VECM) technique to analyze the long run and short run impact of disaggregated remittances that is Migrants 'Remittances and Workers' Remittances to find out whether they will perform differently in relation to economic growth in Nigeria. The two components of remittances performed differently. While the Migrants remittance component exhibits a long run positive, statistically significant relationship with economic growth, the other component i.e Workers Remittance has a negative statistically significant impact in the long run, short run relationship was also established among the variables as the ECM term was negative and statistically significant. The results showed a unidirectional causality from GDP per capita to Migrants remittances while no causality was found between workers' remittances and gross domestic product per capita. The study therefore recommends the need to strategically harness the contribution of workers' remittances by ensuring that the money is spent on locally produced goods instead of imported goods so as to ensure a positive relationship with economic growth in Nigeria. The study hereby concludes that remittance is a major driver of economic growth in Nigeria.
\end{abstract}

Keywords: Remittances, Migrants' remittance, Workers’ remittance, economic growth.

https://dx.doi.org/10.4314/ejeb.v6i2.4

\footnotetext{
1 Associate professor, Department of Economics, University of Lagos Mobile: 08165926969, E-mail: mloto@unilag.edu.ng

2 Department of Economics, Accounting and Finance, Bells University of Technology, Ota, 08056387911, E-mail: aaajibola@bellsuniversity.edu.ng
} 
Remittances and the Growth of the Nigerian Economy

\section{Introduction}

Growth of the economy and the sources of growth have been seriously debated upon. Growth is said to be determined by various factors of which remittances happens to be one of them. Remittance is a component of capital flow to a country, which is proposed to have a direct or indirect impact on economic growth. Increased globalization is a major factor that enhances massive remittance flows (Maimbo \& Ratha, 2005). The tradition of migration is largely due to labour surpluses in most developing countries many of whom are trained or skilled and are unable to get a meaningful employment and as a result tried to look for greener pastures (Fagerheim, 2015). The increased outflows of migrants is expected to be correlated with increased inflow of remittances as many of the migrants feel a sense of obligation to provide financial assistance to their family in their country of origin (Fagerheim, 2015).

As a matter of fact, a positive correlation was reported by Carling (2008) between remittances and household sizes at the country of origin with a negative association to households at the country of destination. Researchers have not reached a consensus on whether or not how the remittance is used has significant impact on economic growth for the recipient country. If the remittances received are for consumption purposes rather than capital investments, the tendency is that there may be very little or inconsequential impact on economic growth for the recipient country. According to Lucas and Stark (1985) economic growth can receive a significant boost only if the remittance flows are invested on livestock or fixed capital. Remittance inflow is largely linked with the theory of migration, the tenure of migration whether temporary or permanent, internal or international.

Authors in the literature especially Bichaka et al. (2008) came up with the findings that remittances boost growth in countries where the financial systems are less developed. It has been argued severally that remittances will provide an alternative way to finance investment and helping the countries to overcome liquidity constraints. Debate on remittances as a source of growth has been a serious argument in the body of literature especially for the developing countries. Giuliano and Ruiz-Arranz (2006) believed that, for the developing countries, remittances represent a major part of international capital flows. They also believed that the impact of remittances is more than that of foreign direct investment (FDI), export revenues, and also foreign aid.

Remittances are also widely viewed as compensatory transfers between family members who lost skilled workers due to migration. The direct and indirect 
Remittances and the Growth of the Nigerian Economy

impact of remittances on family members and on economic growth needs to be properly flogged. The literature shows that in the world, the highest recipient of remittances is the Indian nation, followed by the Nigerian economy. Remittances exhibit variability among nations and it constitutes a greater percentage of the receiving nation's Gross domestic products. The remittances could affect a nation's economic growth positively by improving capital accumulation. It can also improve a nations' economic growth by impacting on the development of the financial sector. It is important to say that remittances could have either positive or negative impacts on economic growth. Remittances could be disaggregated into:

i. Workers' remittances

ii. Migrants' remittances

Workers' remittances - that is, the remittances of workers living abroad to families at home

Migrant/Transfers - that is remittances of those who want to change their base back home from abroad to come and invest at home.

The macroeconomic impact of remittance could be disaggregated, and one could be interests in how remittances impact imports and export, exchange rate and the stock of migrants while the microeconomic impact will consider two household perspectives such as the usage of the remittances and the remittance sending pattern which depends on the migrant's ability to remit, his income level, education, gender and so on (Lucas \& Stark, 1985; Carling, 2008; Fagerheim, 2015).

Remittance inflows from migrant workers is a significant source of capital flows globally and more particularly in the developing countries with a particular focus on Africa (Adeyi, 2015; Adarkwa, 2015). A suggestion by a theoretical strand stated that: Workers' remittances are mainly used for consumption purposes and hence, have nominal impact on investment. Remittances are also widely viewed as compensatory transfers between family members who lost skilled workers due to migration. Migrant remittances are usually used for investment. Remittances are said to be profit-driven and increase when economic conditions in the domestic economy improves. Remittances have become a viable source of external capital and also forms of foreign exchange earnings for individuals and also for nations especially the developing nations (Adeyi, 2015).

A great attention is now being devoted to remittances as a form of source of economic growth. The size of the remittances being received especially by 
developing countries is very important. The degree to which is affecting or contributing to economic growth needs to be investigated, and also the impact of each of the components of remittances to the receiving nations needs to be investigated.

\subsection{Statement of the Problem}

Nigeria is the leading recipient of remittances in Africa, with implications that more Nigerians are resident outside the country compared to other African countries. This is an indication of the underdeveloped state of the economy, the prevalent lack of opportunities and underemployment (Adeagbo \& Ayansola, 2014). This is a situation known as brain drain, involving the exodus of skilled/trained/professional manpower in search of greener pastures. Could there be any appreciable gain from this phenomenon called brain drain? This can be asserted by examining the impact of remittance inflows on the Nigerian economy. Despite huge remittances received by the country, the problems of poverty, unemployment and inequality still persist and indication that Nigeria may not have efficiently utilized the gain from brain drain in terms of remittances (Adeagbo \& Ayansola, 2014) hence, the need to examine the impacts of remittance inflows on economic growth in Nigeria.

It is also possible that the increases in remittances is an illusion resulting from changes in measurements and may not reflect the real financial inflow. Even if the increases are accurately measured cross country regression would not be able to detect the true effects of remittances on economic growth, hence a country specific study is appropriate (Clemens \& McKenzie, 2014).

The impact could be negative or positive; his impact varies from country to country. The direct and indirect impact of remittances on economic growth needs to be properly flogged. Although, the direct and indirect impact have been investigated upon to a reasonable extent. But, because remittances have its component parts too Remittances need to be disaggregated into its component parts in order to know the component that contributes effectively to economic growth. This is still a gap in the literature that is yet to be properly identified, and most especially as it affects the developing countries and Nigeria as a country. This present study is to investigate this gap for the Nigerian economy.

\subsection{Objectives of the Study}

The broad objective of the study is to determine the impact of remittances on economic growth in Nigeria. The specific objective is: 
i. To investigate the responsiveness of the components of remittances (workers remittance and migrant remittance) on economic growth

The rest of the paper is organised as follows: Following from the introductory section, Section 2 is the review of the literature. Section 3 is devoted to the specification of growth model that incorporates remittances as a source of economic growth. Section 4 is devoted to the empirical findings and finally, section 5 is the summary, conclusion and recommendations.

\section{Literature Review}

Fagerheim (2015) investigated the impact of remittances on economic growth in the association of south East Asian nations (ASEAN) from 1980 to 2012 using ordinary least square regression (OLS) and instrumental variable two stage least square (IV 2SLS) method. In the presence of no endogeneity, the OLS result was upheld. The study revealed that remittances have mixed impacts on economic growth.

Adeyi (2015) examined remittances and economic growth in Nigeria and Sri Lanka from 1985 to 2014 using granger causality under the vector autoregressive (VAR) framework. The study found a uni-directional link in Nigeria from remittance inflows to economic growth while a bi-directional causality was found for Sri Lanka between remittances and economic growth. The study therefore recommended the need to employ remittances for small and medium scale enterprise development coupled with the creation of enabling macroeconomic environment.

Adarkwa (2015) examined the impact of remittances on economic growth among selected West African countries from 2000 to 2010 in a linear regression model. The study found that remittance inflow was positively related to economic growth for Nigeria and Senegal while a negative impact was observed for Cameroun and Cape Verde. The study concluded that remittance inflows must be invested in the productive sector before it can positively impact economic growth.

Adeagbo and Ayansola (2014) conducted a review of empirical studies on the impact of remittances on economic development in Nigeria by comparing the positive impacts of remittances on economic development in some countries to the impact of remittances on economic development in Nigeria. The study identified bureaucratic nature of the business climate, over reliance on crude oil, non-formulation and implementation of adequate remittance programmes 
Remittances and the Growth of the Nigerian Economy

political instability and corruption as the major factors working against the positive impacts of remittances in Nigeria.

Kunofiwa (2015) investigated the causal relationship between personal remittances and economic growth in Israel from 1975 to 2011 in a tri-variate causality framework with banking sector development as the third variable. The study employed Johansen co-integration test and the vector error correction model. The results showed that a significant long run relationship exists from economic growth and banking sector development to remittances while the long run causality from personal remittances to economic growth and banking sector development was found to be insignificant. Also no short run causal relationship exists among the variables.

Fayomi, Azuh and Ajayi (2015) investigated the impact of remittances on the Nigeria's economic growth with a case study of Nigerian Diasporas in Ghana using primary data obtained through a questionnaire designed for 326 respondents living in Ghana. The study employed non-parametric tests as well as linear regression for the analysis. Findings revealed that remittances from the Nigerian Diasporas living in Ghana had significant impact on economic growth. The study therefore recommended the installation of adequate infrastructure that could attract more remittances for the country.

Okoduwa, Ewetan and Urhie (2015) in an examination of remittance expenditure pattern and human development outcomes, using household survey data on migration and remittances in the sub Saharan Africa 2009/2010, found that negligible portions of the remittances were actually committed to investment purposes, hence, the insignificant impact on human development outcomes.

Akinpelu. Ogunbi, Bada and Omojola (2013) explored the effects of remittance inflows on economic growth in Nigeria from 1991 to 2011. The study found a unidirectional causality from GDP to remittance inflows.

Theke (2012) examined the effect of remittances on the Nigerian economy from 1980 to 2008 using regression analysis. The study found a positive statistically significant relationship between remittances and economic growth for the periods covered.

Aboulezz (2015) examined the nexus between remittances and economic growth in Kenya from 1993 to 2014 using granger causality test in the framework of autoregressive distributed lagged models (ARDL). International 
remittances indicators were found to be significant determinants of economic growth for the Kenyan economy. The study therefore concluded that economic growth in Kenya was largely driven by remittances for the periods considered. Ahmad (2015) examined workers remittances and economic growth in Jordan from 1975 to 2013 using the ordinary least squares (OLS) technique. The study found a positive relationship between remittances and economic growth. The study concluded that remittances in Jordan were used for both consumption and investment purposes given its positive impact on GDP per capita as a proxy for economic growth.

Kanchan and Bimal (2014) examined the relationship between remittances and economic growth in Bangladesh from 1975 to 2011 using autoregressive distributed lagged (ARDL) model framework. The study found a long run relationship between remittances and GDP although no short run causal relationship was found.

Sources of economic growth has been a major topic in the economic literature. What actually constitute economic growth, especially in developing countries? A number of researchers have contributed the discussion with respect to the determinants of economic growth Lewis (1954), Solow (1956), Chenery and Strout (1966), Denison (1967), Myrdal (1968), Harris and Todaro (1970), Schultz (1979), Fields (1980), Romer (1986), Lucas (1988), Barro (1991), Easterly (2011).

What these authors identified as the sources of economic growth include: surplus labour, physical capital investment, technological change, foreign aid, FDI, investment in human capital, increasing returns from investment in new ideas and research and development. Other additions by other researchers include: institutional factors such as role of political freedom, political instability, voice and accountability on economic growth and development.

In a World Bank study of 2006, it was suggested that recorded remittances have grown faster than foreign direct investment or Official Development Assistance (ODA).

Yilmaz, (2015) investigated the causal relationship among the real GDP per capita growth, personal remittances received and net foreign direct inflows in the transition economies of the European Union including Bulgaria, Croatia, Czech Republic, Hungary, Poland, Romania among others between 1996 and 2013, and the author discovered that there is no causal relationship from 
Remittances and the Growth of the Nigerian Economy

remittances and foreign direct investment inflows to the economic growth. Bichaka et al. (2008) came up with his own result, that remittances boost growth in countries where the financial systems are less developed, whereby they can overcome liquidity constraints. The study was carried out on 37 African countries.Gupta et al (2007) stressed that remittances are neither a panacea nor a substitute for a sustained and domestically engineered development endeavour for curing the problems of low-income countries. Baraja et al (2009) believed that remittances may affect the economic growth positively by increasing the capital accumulation.

According Nyamongo et al (2012), those who receive remittance regarded it as a substitution for labour income and they increase their leisure times and thereby affect economic activity negatively. Ramirez (2013) investigated the Latin American and the Caribbean countries between 1990 and 2007. He came out with a positive impact of remittances on economic growth. Lin and Simmons (2015) investigated the Caribbean community and common market, using the Panel cointegration test. They came up with a no-significant relationship between remittances and economic growth in the long-run. The Component of Capital Inflow comprises of: Remittances, FDI, and Portfolio. It depends on how the remittances are being used by the recipients. It may not be used in the productive investment project.

The remittances could be used for consumption as a result, the impact on economic growth could be negative, the recipient regards the remittances as a substitution for labour income and they increase their leisure times and affect economic activity negatively. Also, exchange rate appreciation could also cause a negative impact on economic growth which may decrease the competitiveness of a country and decrease the export and increase the import bill. Remittance is a component of capital flow to a country. The direct and indirect impact of remittances between remittances and economic growth needs to be properly flogged. This could be explored within the conventional neoclassical growth framework. This study discovered that remittances boost growth in countries where the financial systems are less developed by providing an alternative way to finance investment and helping to overcome liquidity constraint. International capital flows and the growth of the economy especially in SSA, the belief is that the study on this area of research is very scanty. There is need to study thoroughly this area of research especially for the Nigerian economy. This study will provide evidence of the extent to which the remittances can spur economic growth while accounting for the conventional sources of economic growth using standard theory. Bichaka et al. (2008) stated that his study shows that 
Remittances and the Growth of the Nigerian Economy

remittances have statistical significant contribution to both the current level of GDP and the economic growth rate of a nation.

Remittances are also widely viewed as compensatory transfers between family members who lost skilled workers due to migration. Stahl and Arnold (1986) believed that the use of remittances for consumption may have a positive effect on growth because of their possible multiplier effect. Remittances respond to investment opportunities in the home country as much as charitable or insurance motives. Many migrants invest their savings in small businesses, real estate or other assets in their own country. Remittances are said to be profit-driven and increase when economic conditions improve back home. Some authors believed that it is difficult to predict the direction of the impact of remittances on economic growth of SSA economies.

\section{Theoretical Framework and Model Specification}

Economic growth is a major focus on economic literature and the sources of growth have generated a lot of controversies. The popular growth theory and model have been the one propounded by Solow (1956), Lewis (1954), Myrdal (1968), Harris and Todaro (1970), Romer (1986) among others. These set of economists believed that the sources of economic growth begins with surplus labour to physical capital investment and supported by technological, change, foreign aid, foreign direct investment, investment in human capital, research and development. Remittance has been classified as major component of international capital flow and is seen as a major source of economic growth. The importance of remittances has been incorporated as a source of growth in a conventional neoclassical growth model. The theories on economic migrants' remittances could be classified as follows:

We have the classical theory that believed in capital transfer and industrialisation to poor nations to move the economic forward. The neoclassical theory believed in marginal labour productivity and wage level increase in the migrant sending societies. The Neo-Marxist theory believed that migration and remittances will produce and reinforce the capitalist way of dealing with inequalities. The cyclical remittance theory is closely related to the motives for the drive remittances. Also, motives have direct implications for the timing, volume and also their spread among countries and their states of the economy whether it is the receiving country or the donor country. 
Remittances and the Growth of the Nigerian Economy

\section{Methodology}

In this study, a time series data, spanning from 1980 - 2016 was used. The study used the linear Cobb-Douglas production function to estimate the influence of remittances in a disaggregated form on economic growth in the Nigerian economy.

\section{Econometric Methodology}

The focus of the paper is centred on the relationships between remittances and economic growth. To achieve this we specify the production function in the form:

$G D P K_{i t}=B_{0}+B_{1} M_{R E M_{i t}}+B_{2} R E M W_{i t}+B_{3} K A P_{i t}+B_{4} F A_{i t}+B_{5} T R A D E_{t t}+\varepsilon_{i t} \ldots \ldots \ldots \ldots \ldots . .1$

Where:

$L G D P K=$ natural log real GDP per capita

$L M R E M=$ natural log Migrants' remittances (proxy by personal remittances)

$L R E M W=$ natural $\log$ Workers remittances

$L K A P=$ natural $\log$ Gross fixed capital formation which stands for domestic investment in physical capital

$L F A=$ natural $\log$ Foreign Aids (proxy by total bi-lateral aids) as external sources of capital

$L T R A D E=$ natural $\log$ of Trade openness measured by the sum of export and import to GDP ratio

$\varepsilon=$ error term

In the presence of co-integration among the variables of interest, the following augmented form of causality test which involves the error correction term is stated in a bivariate Kth order vector error correction model (VECM) as follows (Ferda, 2007; Nwosa \& Akinbobola 2012):

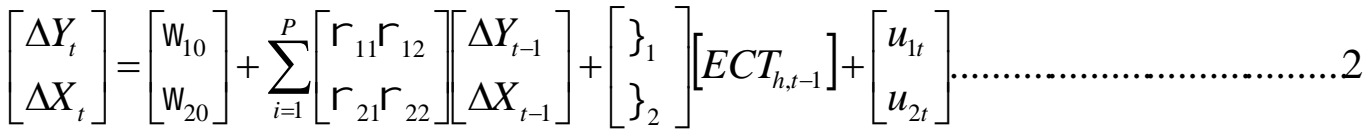

Where $Y_{t}$ refers to LGDPK and $X_{t}$ represents (LMREM, LREMW, LKAP, LFA and LTRADE). ECT is the error correction term.

The variables will be tested for stationarity.

The data used are sourced from the following sources:

(i) Statistical Bulleting of the Central Bank of Nigeria.

(ii) World Development Indicator. 
Remittances and the Growth of the Nigerian Economy

\section{Empirical Results and Interpretation}

\begin{tabular}{|c|c|c|c|c|c|c|}
\hline \multicolumn{7}{|c|}{ 5.1 Empirical Analysis } \\
\hline & GDPK & MREM & REMW & FA & TRADE & KAP \\
\hline Mean & 252111.4 & $6.64 \mathrm{E}+09$ & $6.48 \mathrm{E}+09$ & $8.28 \mathrm{E}+08$ & 0.302057 & $3.17 \mathrm{E}+10$ \\
\hline Median & 214460.7 & $1.17 \mathrm{E}+09$ & $7.93 \mathrm{E}+08$ & $1.98 \mathrm{E}+08$ & 0.3181 & $1.91 \mathrm{E}+10$ \\
\hline Maximum & 385227.6 & $2.11 \mathrm{E}+10$ & $2.08 \mathrm{E}+10$ & $1.1 \mathrm{E}+10$ & 0.5892 & $7.03 \mathrm{E}+10$ \\
\hline Minimum & 173011.9 & 2000000 & 2424527 & 16310000 & 0.0736 & $1.2 \mathrm{E}+10$ \\
\hline Std. Dev. & 71214.58 & $8.91 \mathrm{E}+09$ & $8.88 \mathrm{E}+09$ & $2 \mathrm{E}+09$ & 0.128719 & $2.04 \mathrm{E}+10$ \\
\hline Skewness & 0.683609 & 0.77931 & 0.782505 & 4.116026 & -0.05379 & 0.774922 \\
\hline Kurtosis & 1.899875 & 1.675338 & 1.67503 & 20.0393 & 2.272448 & 1.93531 \\
\hline Jarque-Bera & 4.74766 & 6.450371 & 6.482404 & 552.0776 & 0.833893 & 5.450691 \\
\hline Probability & 0.093123 & 0.039748 & 0.039117 & 0 & 0.659056 & 0.065524 \\
\hline Sum & 9328121 & $2.46 \mathrm{E}+11$ & $2.4 \mathrm{E}+11$ & $3.06 \mathrm{E}+10$ & 11.17612 & $1.17 \mathrm{E}+12$ \\
\hline Sum Sq. Dev. & $1.83 \mathrm{E}+11$ & $2.85 \mathrm{E}+21$ & $2.84 \mathrm{E}+21$ & $1.45 \mathrm{E}+20$ & 0.596469 & $1.5 \mathrm{E}+22$ \\
\hline Observations & 37 & 37 & 37 & 37 & 37 & 37 \\
\hline
\end{tabular}

Source: Authors Computation, 2018

Table (1) revealed the summary statistics of the selected variables for this study. On the average, per capita GDPK, Migrants' remittances (MREM), workers' remittances (REMW), Foreign aids (FA), trade openness (TRADE), and gross fixed capital formation (KAP) are \#2521.4b, \#6.6b, \#6.4b, \#8.2b, 0.3 and \#3.17b respectively. Aside trade openness (Trade); all other variables are positively skewed. In term of distribution, trade openness has the least deviation from mean. Meaning that, it reflects a normal distribution pattern compared with other variables. The stationarity of the selected variables was also performed using the Augmented Dickey-Fuller unit root test.

\subsection{Trend Analysis}

Trend analysis on fig 1 for the periods 1980 to 2016 showed that none of the selected variables has a cyclical pattern. Upward and downward trend was observed in foreign aids, gross domestic product per capita, gross capital formation, migrants' remittances and trade openness, especially trade openness and gross fixed capital formation. 
Remittances and the Growth of the Nigerian Economy

Figure 1: Trend of Foreign Aids, GDP per capita, Capital, Migrants' Remittances, Workers' Remittances and Trade Openness from 1980 to 2016.
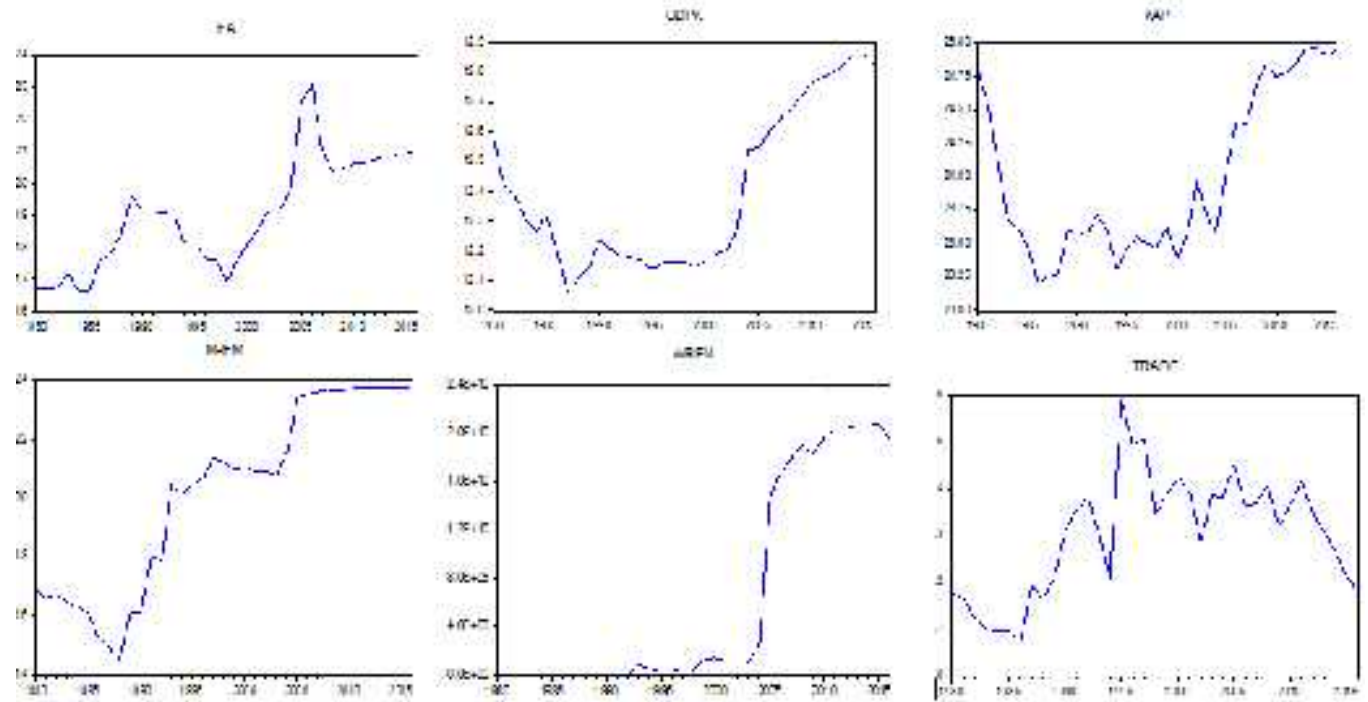

Source: Authors Computation, 2018

Table 2: The Unit root Test.

$\begin{array}{lllcll}\text { Variables } & \text { ADF } & \text { Critical } & \text { ADF FIRST } & \text { Critical } & \text { Order of } \\ & \text { LEVEL } & \text { value 5\% } & \text { DIFFERENCE } & \begin{array}{l}\text { value 5\% } \\ \text { iteration }\end{array} \\ \text { GDPK } & -0.165992 & -2.945842 & -4.850555 & -2.948404 & \text { I(1) } \\ & (0.9340) & & (0.0004) & & \\ \text { KAP } & -0.812314 & -2.954021 & -3.311084 & -2.954021 & \text { I(1) } \\ & (0.8024) & & (0.0224) & & \\ \text { MREM } & -1.161178 & -2.951125 & -4.559004 & -2.948404 & \text { I(1) } \\ & (0.6795) & & (0.0009) & & \\ \text { FA } & -1.376926 & -2.945842 & -4.780982 & -2.948404 & \text { I(1) } \\ & (0.5826) & & (0.0005) & & \\ \text { TRADE } & -1.810198 & -2.945842 & -7.446549 & -2.948404 & \text { I(1) } \\ & (0.3698) & & (0.0000) & & \\ \text { REMW } & -0.648600 & -2.945842 & -6.370770 & -2.948404 & \mathrm{I}(1) \\ & (0.8469) & & (0.0000) & & \end{array}$

Source: Authors Computation, 2018

The unit root test as shown by table 2 shows that all the selected variables became stationary at first difference. Hence, they are integrated of order one. This is a pre-condition for co-integration test. Therefore, this study will adopt 
Remittances and the Growth of the Nigerian Economy

the Johansen-Joselius co-integration test to determine the existence or otherwise of a long run relationship among the variables and as well estimate the relationship between gross domestic product per capita and the selected explanatory variables.

The Johansen co-integration test result is as presented in the tables 3 and 4 below which indicates the trace test and maximum eigenvalue results:

Table 3: Trace Test co-integration result

\begin{tabular}{|c|c|c|c|c|}
\hline \multicolumn{5}{|c|}{ Unrestricted Co-integration Rank Test (Trace) } \\
\hline Hypothesized & & Trace & 0.05 & \\
\hline No. of CE(s) & Eigenvalue & Statistic & $\begin{array}{c}\text { Critical } \\
\text { Value }\end{array}$ & Prob. $* *$ \\
\hline None $*$ & 0.837859 & 204.2769 & 125.6154 & 0.0000 \\
\hline At most 1 $*$ & 0.801523 & 140.6017 & 95.75366 & 0.0000 \\
\hline At most 2* & 0.635598 & 84.00390 & 69.81889 & 0.0024 \\
\hline At most 3* & 0.422571 & 48.67147 & 47.85613 & 0.0418 \\
\hline At most 4 & 0.375374 & 29.45050 & 29.79707 & 0.0548 \\
\hline At most 5 & 0.275114 & 12.97944 & 15.49471 & 0.1156 \\
\hline At most 6 & 0.047915 & 1.718519 & 3.841466 & 0.1899 \\
\hline \multicolumn{5}{|c|}{ Trace test indicates 4 co-integrating eqn.(s) at the 0.05 level } \\
\hline * denotes rejection of the hypothesis at the 0.05 level \\
\hline **MacKinnon-Haug-Michelis (1999) p-values & \\
\hline
\end{tabular}

Source: Authors Computation, 2018

Table 3 above presents the unrestricted co-integration rank trace test result for the variables employed in this study. Trace test revealed the existence of 4 cointegrating equations which indicate the possibility of long run association among the variables employed in the study. While table 4 below presents the unrestricted co-integration rank test for the maximum eigenvalue. The maximum eigenvalue also leads to the rejection of the null hypothesis that no co-integration exists among the variables employed in the study. Eigenvalue statistics revealed the presence of 3 co-integrating equations which implies the possibility of long run association among the variables of interest. 
Remittances and the Growth of the Nigerian Economy

Table 4: Maximum Eigenvalue co-integration result Unrestricted Co-integration Rank Test (Maximum Eigenvalue)

\begin{tabular}{|c|c|c|c|c|}
\hline Hypothesized & & Max-Eigen & 0.05 & \\
\hline No. of CE(s) & Eigenvalue & Statistic & $\begin{array}{c}\text { Critical } \\
\text { Value }\end{array}$ & Prob.** \\
\hline None * & 0.837859 & 63.67514 & 46.23142 & 0.0003 \\
\hline At most 1 * & 0.801523 & 56.59784 & 40.07757 & 0.0003 \\
\hline At most 2 $*$ & 0.635598 & 35.33244 & 33.87687 & 0.0333 \\
\hline At most 3 & 0.422571 & 19.22097 & 27.58434 & 0.3976 \\
\hline At most 4 & 0.375374 & 16.47106 & 21.13162 & 0.1985 \\
\hline At most 5 & 0.275114 & 11.26092 & 14.26460 & 0.1416 \\
\hline At most 6 & 0.047915 & 1.718519 & 3.841466 & 0.1899 \\
\hline Max-eigenvalue test indicates 3 co-integrating eqn.(s) at the 0.05 level \\
\hline \multicolumn{5}{|c|}{$* *$ MacKinnon-Haug-Michelis (1999) p-values } \\
\hline
\end{tabular}

Source: Authors Computation, 2018

With the evidence of a long run relationship among the variables employed in the model, it is important to examine the impact as well as causality between the dependent and the independent variables employed in the model; this will be examined by employing the vector error correction mechanism (VECM).

The VECM analysis is presented in tables $5 \mathrm{~m}$ and 6 below indicating the long run and short run analysis of the model.

Table 5: VECM Long run Estimate

\begin{tabular}{|c|c|c|c|c|c|c|c|c|}
\hline \multirow{2}{*}{ 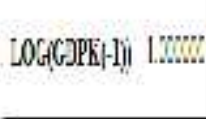 } & LOGOREYU & 1.0060 & LOGREYUT:- & 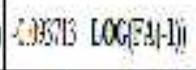 & 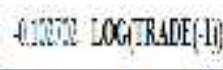 & 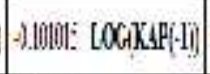 & MEe & 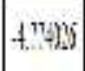 \\
\hline & & (B) & & $(\mathrm{OM}$ & angi & (2.:3) & (2).133is! & \\
\hline & & 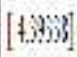 & & {$[-|y| y+\}^{\circ}$} & $[734 y)]$ & {$[-0 i, 8 \pi]$} & {$[-12 E M]$} & \\
\hline
\end{tabular}

Source: Authors Computation, 2018

The VECM estimate revealed that a statistically significant, positive long run relationship exist between first lagged value of per capital GDP LOG(GDPK (1)) and first lagged value of migrants remittances LOG(MREM (-1)) while a negative and statistically significant relationship was found between LOG(GDPK (-1)) and first lagged value of workers remittances LOG(REMW ($1)$ ), first lagged value of gross fixed capital formation as a measure of domestic 
investment (KAP (-1)), first lagged value of foreign aids LOG(FA(-1)) and first lagged value of trade openness LOG(Trade (-1)).

The positive relationship between gross domestic product per capita and migrants' remittances implies that increases in migrants' remittances could boost economic growth in Nigeria. While workers remittances exhibited a negative relationship with the gross domestic product per capita contrary to the findings of Adeyi, (2015) and Adarkwa, (2015) but in conformity with the finding of Ahmad (2015), implying that any increases in the workers' remittances could be inimical to the growth of the Nigerian economy. This is consistent with the arguments in theory that workers remittances may be largely spent on consumption of imported commodities and as such would not be able to promote economic growth in the domestic economy.

Table 6: VECM Short run Estimates

\begin{tabular}{|c|c|c|c|c|c|c|c|c|c|c|c|c|c|}
\hline ICSA-A & 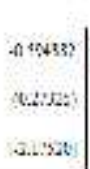 & 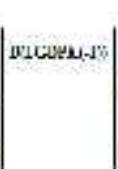 & 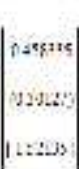 & Dacanesian) & 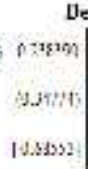 & 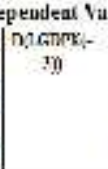 & 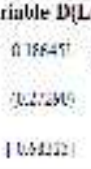 & 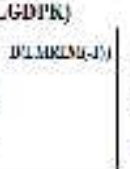 & 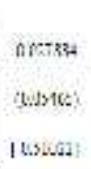 & 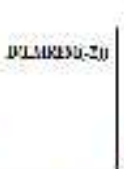 & 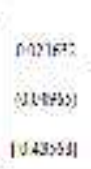 & एLukasu-su| & 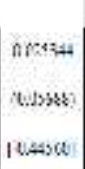 \\
\hline חI.RENW-IW & 000172 & D,TRM:- & tosts: & \begin{tabular}{|c|} 
DLRLLET \\
3n
\end{tabular} & secesos & nYFN-ln & $00: 55$ & 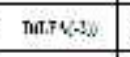 & oogers 3 & 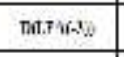 & sem & $\begin{array}{c}\text { PLLLRAUE } \\
\text { LE }\end{array}$ & Coj3:4 \\
\hline & $004+55$ & & Mnts: & & (1) & & mons & & moxitis & & (103: & & $(01465$ \\
\hline & amd? & & {$\left[\begin{array}{lll}-1 & 18 \pi m]\end{array}\right]$} & & $\because$ Mas! & & $\because 134 \%$ & & [f:sstis] & & {$[-12 * 47]$} & & [संस23] \\
\hline DUTBADE: & V2hoss & DATRADE I: & to.144: & DUEAFII" & t.toitas & Ditrisa: $: 3)$ & vines. & DAEAPI 2 : & chossic: & c & 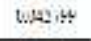 & & \\
\hline & 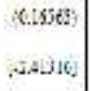 & & Wusm: & & $\begin{array}{l}\text { o.LY:S } \\
\text { A.sYI:4 }\end{array}$ & & 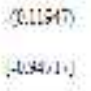 & & colose & & $\begin{array}{l}201517) \\
{[26 s s y]}\end{array}$ & & \\
\hline
\end{tabular}

Source: Authors Computation, 2018

The ECM term (ECM (-1)) is negative and statistically significant, thus short run causal relationship could be implied among the variables employed in this study. Evidence revealed a bi-directional causality between trade openness and gross domestic product per capital. A unidirectional causality was found from GDP per capita to migrants' remittances, domestic investment (proxy by KAP) to migrants' remittances, GDP per capita to foreign aids as well as from trade openness to domestic investment (KAP), while no causality was found between workers' remittances and gross domestic product per capita.

Furthermore, the results of the short run estimates revealed a negative statistically insignificant relationship between GDP per capita and workers' remittances, domestic investments (KAP) and foreign aids (FA). A negative statistically significant relationship also exists between GDPP per capita and 
Remittances and the Growth of the Nigerian Economy

trade openness (Trade) in the short run, while a positive though statistically insignificant relationship was observed between GDP per capita and migrants' remittances in the short run.

The results showed that, in as much as traditional and conventional determinants of economic growth are important, the contribution of remittances are equally very important in bringing about economic growth most especially the migrants' remittances.

The residual serial correlation test was also conducted to check whether the residuals are serially correlated. The test as shown in table 7 revealed that there is no serial correlation among the residuals for the lags specified in the study.

Table 7: Residual Serial Correlation LM Test

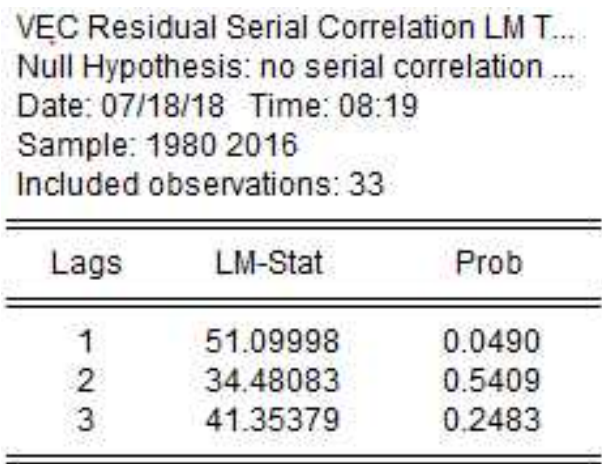

Probs from chi-square with 36 df.

Source: Authors Computation, 2018

\section{Summary, Recommendation and Conclusion}

The study investigated the relationship between remittances and growth of the Nigerian economy. It recognizes the fact that remittance inflow is a component of foreign capital inflow to a country. The role played in economic growth by this component needs thorough investigation. To carry out the analysis, the study made use of secondary data obtained from Central Bank of Nigeria statistical bulletin (2017), World Bank's world development indicator (WDI, 2017). The variables of interest were estimated using Augmented Dickey-Fuller (ADF) test for unit roots, Johansen co-integration techniques and the vector error correction mechanism (VECM). The ADF unit-root test revealed that the variables were all stationary at first difference hence the need for the Johansen co-integration test which revealed evidences of long run relationships among the variables in the model with 4 and 3 co-integrating equation by the trace 
Remittances and the Growth of the Nigerian Economy

statistics and the maximum Eigenvalue statistics respectively. The trend analysis in figure 4.1 of the variables used shows that none of the selected variables is having a cyclical pattern.

The error correction term exhibits the correct sign, that is, negative and it is statistically significant. The $\mathrm{R}^{2}$ stood at 0.65 which means that the explanatory variables explained $65 \%$ of the outcome. On the whole, migrants' remittances influenced GDP per capita positively in a statistically significant manner in the long run while a statistically significant negative relationship exists between workers' remittances and GDP per capita in the long run. However, short run analysis revealed a unidirectional causality from GDP per capita to migrants' remittances while no causality was found between workers' remittances and GDP per capita.

\section{Recommendation}

In as much as it has been established that remittances can boost growth of the economy where the financial system is less developed. It is important that remittances should be encouraged in order to serve as an alternative way to finance investment and also to overcome liquidity constraints. There is need to strategically harness the contribution of workers' remittances by ensuring that the money is spent on locally produced goods instead of imported goods so as to ensure a positive relationship with economic growth in Nigeria. Also, policies that will improve the efficiency and reliability as well as reduction in the cost of transfers should be implemented in order to encourage more inflow of remittances to the Nigerian economy.

\section{Conclusion}

This study concludes that migrants' remittances positively and significantly impact economic growth in the long run, while workers' remittances have a negative statistically significant impact on the growth of the Nigerian economy in the long run. It was discovered that, in the short run, there exists a unidirectional causality from GDP per capita to migrants' remittances while there was no evidence of causality between GDP per capita and workers' remittances in Nigeria for the period of study. Remittance is a potential driver of economic growth in Nigeria. 
Remittances and the Growth of the Nigerian Economy

\section{References}

Aboulezz N. (2015) "Remittances and Economic Growth Nexus: Empirical Evidence from Kenya" International Journal of Academic Research in Business and Social Sciences. Vol. 5 (12) Pp. 285 - 296.

Adarkwa M. A. (2015) "Impact of remittances on Economic Growth: Evidence from selected west African Countries" AHMR. Vol. 11 (2), Pp. 1-16.

Adeagbo O. and Ayansola O. A. (2014) "Impact of Remittances on Development in Nigeria: Challenges and Prospects" Journal of Sociology Soc Anth. Vol. 5(3), Pp. 311-318.

Adeyi E. O. (2015) "Remittances and Economic Growth: An Empirical Evidence from Nigeria and Sri Lanka" Basic Research Journal of Education Research and Review. Vol. 4 (5), Pp. 91-97.

Ahmad A. A. (2015): "Workers Remittances and Economic Growth: Evidence from Jordan" European Scientific Journal. Vol. 11(25), Pp. 40-54.

Akinpelu Y. A., Ogunbi O. J., Bada O. T., and Omojola O. S. (2013) "Effects of Remittance Inflows on Economic Growth in Nigeria" Journal of Development Studies. Vol. 3 (3), Pp. 113-123.

Barajas, A. Chami, R, Fullenkamp, C. Gapen, M. and Montiel, P. (2009): Do workers' remittances promote economic growth? IMF working paper WP (09)/153

Barro, R. (1991): "Economic Growth in Cross-Section of Countries", Quarterly Journal of Economics, 106 (May) 407 - 443.

Bichaka, F., Fayassa and Christian, N. (2008): The Impact of Remittances on Economic Growth and Development in Africa. Department of Economic and Finance Working Papers Series, February (2008).

Carling J. (2008) "The Determinants of Migrants remittances" Oxford Review of Economic Policy. Vol. 24 (3), Pp. 582-599.

CBN (2017) "Statistical Bulletin" Central Bank of Nigeria

Chenery, H.B. and Strout, A. (1966) "Foreign Assistance and Economic Development" American Economic Review, 56(September): 679 - 733.

Clemens M. A. and McKenzie D. (2014) "Why Remittances Appear to affect Growth" Center for Global Development. Working Paper Series 366, Pp.1-49.

Denison, E.F. (1967): Why growth rates differ. Post-War Experience for nine Western Countries. Washington DC.

Easterly W. and Levin, R. (2001): The Elusive Quest for Growth. The MIT Press, Cambridge MA.

Fagerheim M. G. (2015) "Impact of Remittances on Economic Growth in ASEAN" Thesis for Master of Philosophy in Environmental and Development Economics, OSLO University, May 2015.

EJBE Vol. 6 No. 2/2016

Page 226 
Remittances and the Growth of the Nigerian Economy

Fayomi O., Azuh D. and Ajayi L. (2015) "The Impacts of Remittances on Nigeria's Economic Growth: A Study of Nigerian Diasporas in Ghana" Journal of South African Business Research. Vol. (2015) Article ID. :598378, Pp. 1-12.

Fields, G.S. (1980): Poverty, Inequality and Development, The MIT Press, Cambridge University Press, England.

Giuliano, P. And Ruiz - Arranz, M. (2006) "Remittances, Financial Development and Growth," IMF Working Papers, WP 05/234.

Gupta, S. Pattillo, C. and Wagh, S. (2007): "Making remittances work for Africa", Finance and Development 44, No. 2 (June, 2007): 1 - 9.

Harris, I.R.M., Todaro (1970) "Migration, Employment and Development: A Two-Sector Analysis, American Economic Review, 60(March): 126 142

Iheke O. R. (2012) "The Effect of Remittances on the Nigerian Economy" International Journal of Development and Sustainability. Vol. 1 (2), Pp. 614-621.

Kanchan D. and Bimal S. (2014) "Relationship between Remittances and Economic Growth in Bangladesh: An Econometric Study. Bangladesh Development Research working Paper Series. Pp. 1-14.

Kunofiwa T. (2015) "Personal Remittances, Banking Sector Development and Economic Growth in Israel: A tri-variate Causality Test" Journal of Corporate Ownership and Control. Vol. 13(1), Pp. 806-819.

Lewis, S.A.W. (1954) "Economic development with unlimited supplies of labour", Manchester School of Economics and Social Studies, 22 (May): $139-191$.

Lin, S. and Simmons, W.O. (2015): Do remittances promote economic growth in the Caribbean community and common market? Journal of Economic and Business 77, pp. 42 - 59.

Lucas, R.E. (1988): "On Mechanics of Economics Growth". Journal of Monetary Economics 22(July): 3 - 42.

Lucas R. E. and Stark O. (1985) "motivation to Remit: Evidence from Botswana" Journal of Political Economy. Vol. 93, Pp. 901-918.

Maimbo S. M. and Ratha D. (2005) "Remittances-Development Impact and Future Prospects" Washington DC. The World Bank.

Myrdal, G. (1968): Asian Drama: An Inquiry into the Poverty of Nations (New York Twentieth Century Fund)

Nyamongo, E.M. Misatib, R.N., Kipyegonb, L., Ndiragin, I. (2012): Remittances, financial development and Economic Growth in Africa. Journal of Economic and Business 64 pp. 240 - 260. 
Remittances and the Growth of the Nigerian Economy

Okodua H., Ewetan O. O. and Urhie E. (2015) "Remittance Expenditure Patterns and Human Development Outcomes in Nigeria" Journal of Developing Countries Studies. VOl. 5(2), Pp. 70-81.

Ramirez, M.D. (2013): Do financial and institutional variables enhance the impact of remittances on economic growth in Latin America and the Caribbean? A Panel Cointegration Analysis. International Advances in Economic Research 19, pp. 273 - 288.

Romer, P. (1986): "Increasing Returns and Long-Run Growth" Journal of Political Economy, (October), 1002 - 1037.

Schultz, T.W. (1979): “The Economics of Being Poor". Journal of Political Economy (August): $639-650$.

Solow, R. (1956): A contribution to the theory of Economic" Quarterly Journal of Economics, 70(February) $65-94$.

Stahl, C.W. and Arnold, F. (1986) 'Overseas workers' remittances in Asian Development” International Migration Review 20(4): 899 -925.

WDI (2017) "World Development Indicator" World Bank

Yilmaz, B. (2015): Impact of Remittances on the Economic Growth in the Transitional Economies of the European Union. Economic Insight Trends and Challenges. 
Remittances and the Growth of the Nigerian Economy

\section{Appendix}

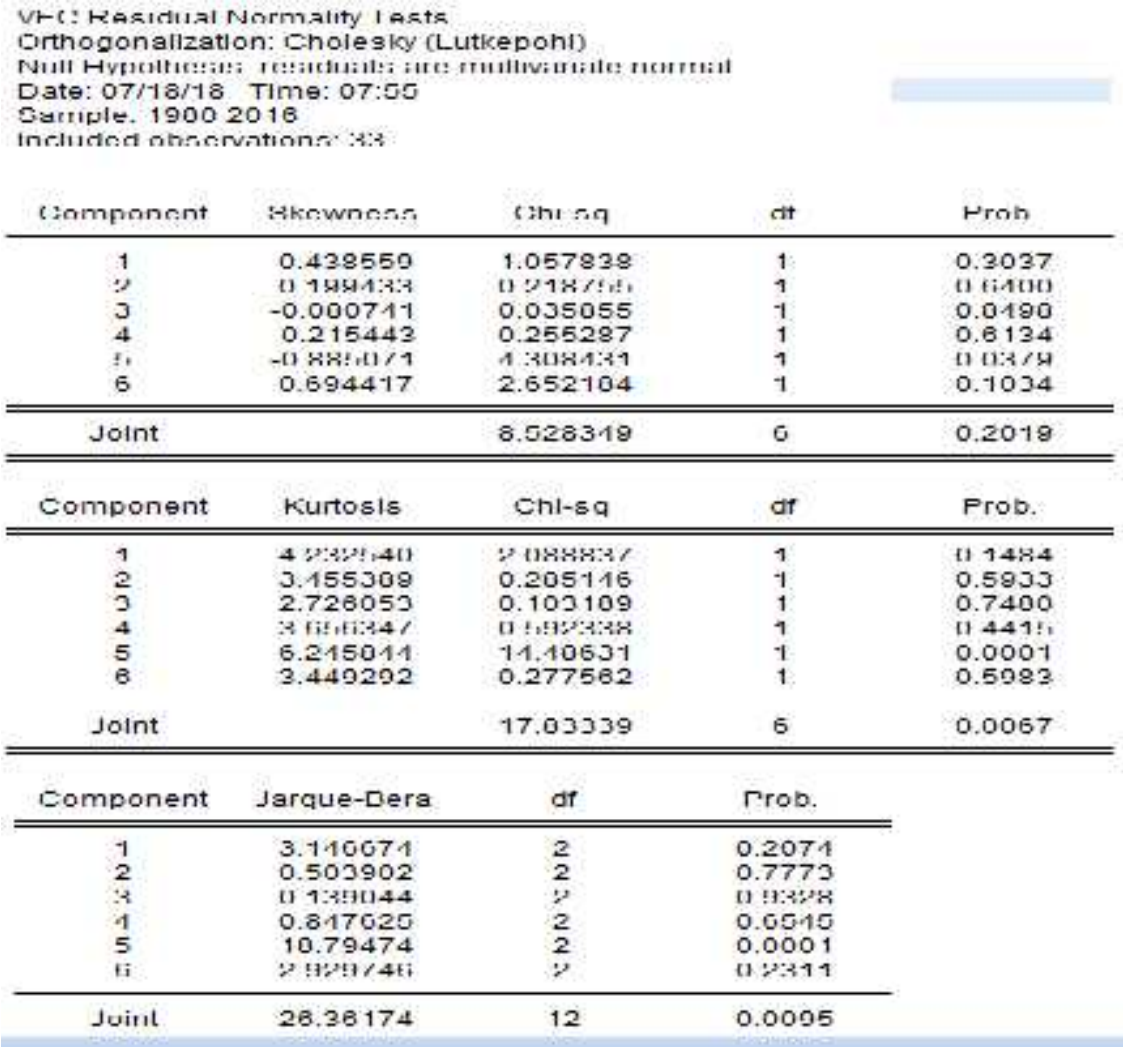

\begin{tabular}{|c|c|c|c|c|c|c|}
\hline $\begin{array}{c}\text { Error } \\
\text { Correction: }\end{array}$ & $\mathrm{D}(\mathrm{LGDPK})$ & D(LMREM) & $\mathrm{D}($ LREMW) & $\mathrm{D}(\mathrm{LFA})$ & $\mathrm{D}(\mathrm{LTRADE})$ & $\mathrm{D}(\mathrm{LKAP})$ \\
\hline \multirow[t]{3}{*}{$\operatorname{ECM}(-1)$} & -0.594382 & -6.392866 & -3.636331 & -2.43817 & -0.849475 & 0.490638 \\
\hline & $(0.27325)$ & $(2.51434)$ & (3.79214) & $(2.70410)$ & $(0.42501)$ & $(0.72279)$ \\
\hline & {$[-2.17520]$} & [-2.54257] & {$[-0.95891]$} & {$[-0.90166]$} & [-1.99874] & [ 0.67881] \\
\hline \multirow[t]{3}{*}{$\begin{array}{c}\text { D(LGDPK(- } \\
1))\end{array}$} & 0.458335 & 8.485285 & 6.586670 & 7.586373 & 0.378285 & 0.095393 \\
\hline & (0.30127) & (2.77211) & (4.18092) & (2.98133) & $(0.46858)$ & (0.79689) \\
\hline & [ 1.52135$]$ & [ 3.06095] & [ 1.57541$]$ & [ 2.54463] & [ 0.80730$]$ & [ 0.11971$]$ \\
\hline \multirow[t]{3}{*}{$\begin{array}{c}\text { D(LGDPK(- } \\
2))\end{array}$} & 0.238390 & 0.860615 & -0.707286 & 3.022168 & 0.751321 & 0.203494 \\
\hline & $(0.34774)$ & (3.19975) & (4.82588) & (3.44124) & $(0.54086)$ & $(0.91982)$ \\
\hline & [ 0.68553] & [ 0.26896] & {$[-0.14656]$} & [ 0.87822] & [ 1.38912] & [ 0.22123] \\
\hline \multirow[t]{2}{*}{$\begin{array}{c}\text { D(LGDPK(- } \\
3))\end{array}$} & 0.186451 & -0.207343 & 0.379652 & 2.592871 & -0.799173 & -0.430973 \\
\hline & $(0.27290)$ & (2.51105) & (3.78718) & (2.70056) & $(0.42445)$ & $(0.72184)$ \\
\hline
\end{tabular}

EJBE Vol. 6 No. 2/2016

Page 229 
Remittances and the Growth of the Nigerian Economy

\begin{tabular}{|c|c|c|c|c|c|c|}
\hline & [ 0.68323] & {$[-0.08257]$} & [ 0.10025$]$ & [ 0.96012$]$ & [-1.88285] & {$[-0.59705]$} \\
\hline \multirow[t]{3}{*}{$\begin{array}{c}\text { D(LMREM(- } \\
1))\end{array}$} & 0.027884 & -0.718191 & -0.500858 & -0.77768 & -0.12837 & 0.049177 \\
\hline & $(0.05465)$ & $(0.50288)$ & $(0.75844)$ & $(0.54083)$ & $(0.08500)$ & $(0.14456)$ \\
\hline & [ 0.51022] & {$[-1.42816]$} & {$[-0.66038]$} & [-1.43793] & {$[-1.51019]$} & [ 0.34018] \\
\hline \multirow[t]{3}{*}{$\begin{array}{l}\text { D(LMREM(- } \\
\text { 2)) }\end{array}$} & 0.021632 & 0.621718 & 0.459584 & -0.60781 & 0.064222 & -0.095295 \\
\hline & $(0.04965)$ & $(0.45686)$ & $(0.68903)$ & $(0.49134)$ & $(0.07722)$ & $(0.13133)$ \\
\hline & [ 0.43568] & [ 1.36086] & [ 0.66700] & {$[-1.23706]$} & [ 0.83163$]$ & {$[-0.72561]$} \\
\hline \multirow[t]{3}{*}{$\begin{array}{l}\text { D(LMREM(- } \\
\text { 3)) } \\
\end{array}$} & 0.025344 & 0.626720 & 0.483436 & -0.40434 & 0.168415 & -0.070467 \\
\hline & $(0.05688)$ & $(0.52335)$ & $(0.78932)$ & $(0.56285)$ & $(0.08846)$ & $(0.15045)$ \\
\hline & [ 0.44560$]$ & [ 1.19751] & [ 0.61247] & {$[-0.71837]$} & [ 1.90377] & {$[-0.46839]$} \\
\hline \multirow[t]{3}{*}{$\begin{array}{l}\text { D(LREMW(- } \\
1))\end{array}$} & -0.034719 & 0.127408 & 0.141108 & 0.535855 & 0.045387 & -0.111846 \\
\hline & $(0.04465)$ & $(0.41080)$ & $(0.61957)$ & $(0.44180)$ & $(0.06944)$ & $(0.11809)$ \\
\hline & {$[-0.77767]$} & [ 0.31015] & [ 0.22775$]$ & [ 1.21288] & [ 0.65363] & {$[-0.94711]$} \\
\hline \multirow[t]{3}{*}{$\begin{array}{l}\text { D(LREMW(- } \\
\text { 2)) }\end{array}$} & -0.086826 & -0.508399 & -0.415826 & 0.188647 & -0.055382 & 0.155416 \\
\hline & $(0.04623)$ & $(0.42541)$ & $(0.64161)$ & $(0.45752)$ & $(0.07191)$ & $(0.12229)$ \\
\hline & {$[-1.87800]$} & {$[-1.19508]$} & {$[-0.64810]$} & [ 0.41233] & {$[-0.77017]$} & [ 1.27087] \\
\hline \multirow[t]{3}{*}{$\begin{array}{l}\text { D(LREMW(- } \\
\text { 3)) }\end{array}$} & -0.060508 & -0.614727 & -0.528169 & 0.093758 & -0.137009 & 0.072519 \\
\hline & $(0.05027)$ & $(0.46258)$ & $(0.69766)$ & $(0.49749)$ & $(0.07819)$ & $(0.13298)$ \\
\hline & {$[-1.20361]$} & {$[-1.32892]$} & {$[-0.75705]$} & [ 0.18846$]$ & [-1.75223] & [ 0.54536] \\
\hline \multirow[t]{3}{*}{$\mathrm{D}(\mathrm{LFA}(-1))$} & -0.055466 & -0.240494 & -0.211104 & -0.20693 & -0.065166 & 0.099132 \\
\hline & $(0.04007)$ & $(0.36870)$ & $(0.55607)$ & $(0.39653)$ & $(0.06232)$ & $(0.10599)$ \\
\hline & {$[-1.38423]$} & {$[-0.65228]$} & {$[-0.37963]$} & {$[-0.52186]$} & {$[-1.04562]$} & [0.93531] \\
\hline \multirow[t]{3}{*}{$\mathrm{D}(\mathrm{LFA}(-2))$} & 0.016048 & -0.040834 & 0.136686 & -0.2635 & 0.044448 & 0.021856 \\
\hline & $(0.02414)$ & $(0.22213)$ & $(0.33503)$ & $(0.23890)$ & $(0.03755)$ & $(0.06386)$ \\
\hline & [ 0.66474$]$ & {$[-0.18383]$} & [ 0.40799] & {$[-1.10298]$} & [ 1.18375$]$ & [ 0.34227$]$ \\
\hline \multirow[t]{3}{*}{$\mathrm{D}(\mathrm{LFA}(-3))$} & -0.027975 & -0.243061 & -0.233638 & -0.05511 & -0.04992 & 0.095547 \\
\hline & $(0.02319)$ & $(0.21336)$ & $(0.32179)$ & $(0.22946)$ & $(0.03606)$ & $(0.06133)$ \\
\hline & {$[-1.20647]$} & {$[-1.13921]$} & {$[-0.72606]$} & {$[-0.24016]$} & {$[-1.38419]$} & [ 1.55782] \\
\hline $\begin{array}{c}\text { D(LTRADE(- } \\
1)) \\
\end{array}$ & -0.008204 & 1.695105 & 1.830827 & 0.347305 & -0.403651 & 0.115377 \\
\hline
\end{tabular}


Remittances and the Growth of the Nigerian Economy

\begin{tabular}{|c|c|c|c|c|c|c|}
\hline & $(0.16467)$ & (1.51522) & (2.28527) & (1.62958) & $(0.25612)$ & $(0.43558)$ \\
\hline & [-0.04982] & [ 1.11872$]$ & [ 0.80114$]$ & [ 0.21313] & {$[-1.57601]$} & [ 0.26488] \\
\hline \multirow[t]{3}{*}{$\begin{array}{l}\text { D(LTRADE }(- \\
2))\end{array}$} & -0.399695 & 2.391369 & 2.168438 & 1.088935 & -0.186698 & 1.028652 \\
\hline & $(0.16563)$ & (1.52405) & (2.29858) & (1.63907) & $(0.25761)$ & $(0.43811)$ \\
\hline & {$[-2.41316]$} & [ 1.56909] & [ 0.94338] & [ 0.66436 ] & {$[-0.72472]$} & [ 2.34792] \\
\hline \multirow[t]{3}{*}{$\begin{array}{l}\text { D(LTRADE }(- \\
3))\end{array}$} & -0.114166 & 0.993337 & 0.219090 & 0.205671 & -0.423811 & 0.117290 \\
\hline & $(0.18270)$ & (1.68109) & (2.53544) & (1.80797) & $(0.28416)$ & $(0.48326)$ \\
\hline & {$[-0.62489]$} & [ 0.59089] & [ 0.08641] & [ 0.11376 ] & {$[-1.49145]$} & [ 0.24271] \\
\hline \multirow[t]{3}{*}{$\mathrm{D}(\operatorname{LKAP}(-1))$} & -0.102249 & -1.793723 & -0.497557 & -1.47552 & -0.168193 & 0.241680 \\
\hline & $(0.12018)$ & (1.10585) & (1.66785) & (1.18931) & $(0.18693)$ & $(0.31790)$ \\
\hline & {$[-0.85079]$} & {$[-1.62203]$} & {$[-0.29832]$} & {$[-1.24065]$} & {$[-0.89979]$} & [ 0.76025] \\
\hline \multirow[t]{3}{*}{$\mathrm{D}(\operatorname{LKAP}(-2))$} & -0.113161 & -2.351243 & -1.89538 & -2.34272 & -0.308895 & -0.154 \\
\hline & $(0.11947)$ & (1.09932) & (1.65801) & (1.18229) & $(0.18582)$ & $(0.31602)$ \\
\hline & {$[-0.94717]$} & [-2.13881] & {$[-1.14317]$} & [-1.98150] & [-1.66232] & {$[-0.48731]$} \\
\hline \multirow[t]{3}{*}{$\mathrm{D}(\operatorname{LKAP}(-3))$} & -0.058775 & -0.089148 & 0.331328 & -0.57466 & -0.005715 & 0.516645 \\
\hline & $(0.10830)$ & (0.99653) & (1.50297) & (1.07174) & $(0.16845)$ & $(0.28647)$ \\
\hline & {$[-0.54270]$} & {$[-0.08946]$} & [ 0.22045] & {$[-0.53620]$} & {$[-0.03393]$} & [ 1.80350$]$ \\
\hline \multirow[t]{3}{*}{ C } & 0.043799 & 0.323727 & 0.295332 & 0.276710 & 0.024581 & -0.001664 \\
\hline & $(0.01647)$ & $(0.15153)$ & (0.22854) & $(0.16296)$ & $(0.02561)$ & $(0.04356)$ \\
\hline & [ 2.65966] & [2.13641] & [ 1.29228] & [ 1.69798] & [ 0.95970] & {$[-0.03820]$} \\
\hline R-squared & 0.656125 & 0.775200 & 0.510884 & 0.753731 & 0.606534 & 0.718686 \\
\hline $\begin{array}{l}\text { Adj. R- } \\
\text { squared }\end{array}$ & 0.153538 & 0.446646 & -0.203978 & 0.393800 & 0.031468 & 0.307535 \\
\hline $\begin{array}{l}\text { Sum sq. } \\
\text { resids }\end{array}$ & 0.047211 & 3.997213 & 9.092408 & 4.623341 & 0.114209 & 0.330318 \\
\hline $\begin{array}{l}\text { S.E. } \\
\text { equation }\end{array}$ & 0.060263 & 0.554507 & 0.836311 & 0.596357 & 0.093730 & 0.159402 \\
\hline F-statistic & 1.305494 & 2.359429 & 0.714661 & 2.094098 & 1.054721 & 1.747987 \\
\hline $\begin{array}{l}\text { Log } \\
\text { likelihood }\end{array}$ & 61.24397 & -11.99495 & -25.55535 & -14.396 & 46.66790 & 29.14445 \\
\hline Akaike AIC & -2.499635 & 1.939088 & 2.760930 & 2.084608 & -1.616236 & -0.554209 \\
\hline $\begin{array}{l}\text { Schwarz } \\
\text { SC }\end{array}$ & -1.59266 & 2.846062 & 3.667905 & 2.991582 & -0.709262 & 0.352765 \\
\hline $\begin{array}{l}\text { Mean } \\
\text { dependent }\end{array}$ & 0.015416 & 0.219577 & 0.235187 & 0.115858 & 0.002418 & 0.038451 \\
\hline $\begin{array}{l}\text { S.D. } \\
\text { dependent }\end{array}$ & 0.065501 & 0.745427 & 0.762182 & 0.765946 & 0.095240 & 0.191556 \\
\hline
\end{tabular}


Remittances and the Growth of the Nigerian Economy

\begin{tabular}{|l|c|l|l|l|l|}
\hline $\begin{array}{c}\text { Determinant resid } \\
\text { covariance (dof adj.) }\end{array}$ & $6.04 \mathrm{E}-10$ & & & & \\
\hline $\begin{array}{l}\text { Determinant resid } \\
\text { covariance }\end{array}$ & $2.26 \mathrm{E}-12$ & & & & \\
\hline Log likelihood & 161.5169 & & & & \\
\hline $\begin{array}{l}\text { Akaike information } \\
\text { criterion }\end{array}$ & -2.152539 & & & & \\
\hline Schwarz criterion & 3.561399 & & & & \\
\hline
\end{tabular}

